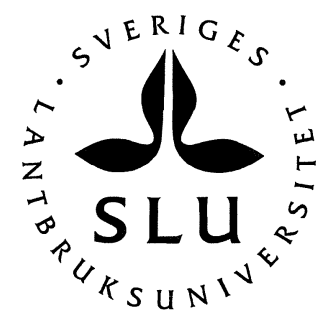

\title{
On the potential of Kriging for forest management planning
}

\author{
Fredrik Gunnarsson
}

Arbetsrapport 131996 


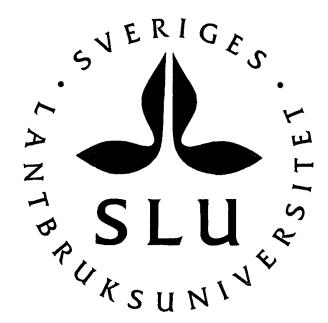

\title{
On the potential of Kriging for forest management planning
}

\author{
Fredrik Gunnarsson
}

Arbetsrapport 131996

Examensarbete i skogsuppskattning och skogsindelning

Handledare: Sören Holm

Peter Holmgren

Tomas Thuresson

SVERIGES LANTBRUKSUNIVERSITET

ISSN 1401-1204

Institutionen för skoglig resurshushållning

ISRN SLU-SRG-AR--13--SE

och geomatik

S-901 83 UMEÅ

Tfn: 090-16 5825 Fax: 090-14 1915 


\section{Sammanfattning}

Detta examensarbete har haft som syfte att undersöka om skogsbruksplaneringsmetoden "Avdelningsfritt skogsbruk" kan tillämpas med tillfredsställande resultat $\mathbf{i}$ södra Sverige. Studien utfördes på Asa skogsvårdsgård ägd av skogsvårdsstyrelsen $i$ Kronobergs län. Fastigheten är belägen strax söder om Asa ca $30 \mathrm{~km}$ norr om Växjö. En pilotstudie har tidigare utförts i Vilhelmina (Holmgren \& Thuresson 1995, 1996).

Vid skogsbruksplanering är det viktigt att ha bra data om skogen att basera beslut på. Lika viktigt är dock att veta noggrannheten hos de skattningar som gjorts för olika skogsbruksplaneringsvariabler. Dessutom är heltäckande data en förutsättning för skogsbruksplanering. På grund av kostnaden för insamling av objektiva data har skogsbruksplanering hittills baserats på subjektiva skattningar på beståndsnivå, möjligen kalibrerade med hjälp av objektivt provytematerial. Lämplig skötsel av dessa bestånd bestäms också subjektivt. Dessa bestånd anses vara homogena avseende viktiga variabler för skogsbruksplanering, $\mathrm{t}$ ex volym, ståndortsindex $\mathrm{mm}$ och förväntas bestå för lång tid. Detta är en förenkling av verkligheten.

Med hjälp av kriging och Geografiska Informations System (GIS) kan man göra heltäckande skattningar av viktiga skogsbruksplaneringsvariabler från objektiva skattningar på provytor. Dessa skattningar åtföljs dessutom av värden för dessa skattningars noggrannhet, något som saknas vid subjektiva skattningar.

Kriging är en geostatistisk metod utvecklad från början inom gruvindustrin, men fullt möjlig att tillämpa på alla variabler som uppvisar spatial autokorrelation, $\mathrm{d}$ v s variabler vars värde för en viss punkt uppvisar likheter med värden för punkter som ligger nära geografiskt. Metoden utnyttjar information (semivariogram) om hur korrelerade värden, för en viss variabel, är på olika avstånd. Informationen används till att med hjälp av ett vägt medelvärde skatta värden för punkter utan information. Vikterna för de olika observationerna bestäms så att variansen för skattningen minimeras.

Då fastigheten i undersökningen, som de flesta fastigheter i södra Sverige, är intensivt skött har den ett fragmenterat utseende med små bestånd. Detta är ett problem vid kriging eftersom skarpa gränser utjämnas, t.ex. blir det ingen skarp gräns i volym mot en hyggeskant. För att komma till rätta med detta problem indelades skogen i fyra stratum efter ålder enligt befintlig skogsbruksplan. De olika stratumen var: under 10 år; 10 - 30 år; 30 - 70 år; 70 år och uppåt. En annan anledning till stratumindelningen var att man i äldre bestånd förlorar mer pengar (nuvärde) på ett felaktigt beslut. Dessutom tillför en flygbild betydligt mer information i yngre bestånd. Av dessa anledningar varierades provytetätheten så att provytorna lades tätare $\mathrm{i}$ äldre stratum.

För att undersöka vilka variabler som kan skattas med hjälp av kriging, framställdes semivariogram för olika variabler. Det visade sig att flera variabler uppvisade spatial autokorrelation och kan alltså skattas med hjälp av kriging. Några av dessa variabler var: totalvolym/ha, ståndortsindex, grundytevägd medeldiameter (dgv), inoptimalförlust vid slutavverkning och volymtillväxt. Tyvärr uppvisade inga 
lövträdsvariabler tillräcklig autokorrelation. Detta kan förklaras av den låga andelen lövträd på fastigheten. Förekomsten av lövträd upplevdes dessutom splittrad.

En utvärdering av krigingresultatet $\mathrm{m} h$ a korsvalidering visade på en liten underskattning av volymen. Denna underskattning var dock så liten att den inte bevisar att skattningen är belastad av bias. Utvärderingen visade också, som väntat, att värdena från krigingskattningen är utjämnade jämfört med värdena i ursprungsmaterialet (variansen betydligt lägre). De högsta volymerna underskattas och de lägsta överskattas.

Många variabler uppvisade de egenskaper som krävs för att kunna skattas med kriging. Egenskapen att skattningarna åtföljs med felskattningar gör att de kan användas till att skapa kombinationsestimat, $t$ ex med skattningar från flygbilder. Precisionen i dessa kombinerade skattningar skulle på detta sätt bli bättre än skattningar med enbart kriging eller flygbilder. 


\section{Förord}

Detta examensarbete på $20 \mathrm{p} \mathrm{(motsvarande} \mathrm{en} \mathrm{termins} \mathrm{studier)} \mathrm{har} \mathrm{utförts} \mathrm{av} \mathrm{Fredrik}$ Gunnarsson för institutionen för skoglig resurshushållning och Geomatik vid Sveriges lantbruksuniversitet i Umeå och Skogsvårdsstyrelsen i Kronobergs län. Handledare har varit Sören Holm, Peter Holmgren och Tomas Thuresson. Kontaktpersoner vid Skogsvårdsstyrelsen i Kronobergs län har varit Rune Ahlander och Jan Karlsson mfl. 


\section{Innehållsförteckning}

Sammanfattning

Förord

$\begin{array}{ll}\text { Abstract } & 1\end{array}$

Introduction $\quad 2$

$\begin{array}{ll}\text { Materials and methods } & 7\end{array}$

$\begin{array}{ll}\text { Results } & 12\end{array}$

$\begin{array}{ll}\text { Discussion } & 17\end{array}$

$\begin{array}{ll}\text { Acknowledgments } & 20\end{array}$

$\begin{array}{ll}\text { References } & 21\end{array}$

Bilaga 1. Krigingresultat, totalvolym / ha 24

Bilaga 2. Krigingresultat, ståndortsindex för gran 25

Bilaga 3. Krigingresultat, inoptimalförlust vid slutavverkning 26

Bilaga 4. Krigingresultat, totalålder alla trädslag 27 


\begin{abstract}
Forest management planning aims at fulfilling the overall goals for the forest owner. The economic optimal scheduling of treatments in spatially discrete forest stands, the time dimension, has been thoroughly investigated in research. The spatial dimension is less investigated. Normally, spatially discrete stands are defined as treatment units. These are inventoried using subjective methods with unknown precision. As an alternative to this conventional way to describe the forest, the present investigation used kriging for estimating forest characteristics spatially continuously using georeferenced sample plots. Using stratification by age, several variables interesting for forest management planning displayed spatial autocorrelation, even though the estate was thoroughly managed. No hardwood variables displayed the autocorrelation necessary for using kriging.
\end{abstract}




\section{INTRODUCTION}

The objective of forestry is often expressed as maximal monetary net present value of the forest, given certain sustained-yield and nature conservation constraints (Jonsson et al. 1993). High precision and accurate complete-cover information about the forest is vital to achieve this goal (Newton \& Bower 1989, Baskent \& Jordan 1991, Elston \& Buckland 1993, Holmgren 1995, Thuresson 1995). To be able to get a good result from the information it is of utmost importance to have well defined and measurable objectives for the forest. Not only the estimated values, but also knowledge about the precision is worthy in forestry planning operations (Newton \& Bower 1989, Elston \& Buckland 1993, Holmgren 1995). Today almost all forestry planning is based on discrete treatment units, stands. They are most often subjectively delineated, to represent units that are homogeneous with respect to planning variables. Stand borders are presupposed to remain unchanged far into the future. However, natural factors will probably, at least after a while, lead to increasing heterogeneity in stands. For example, the annual growth varies within a stand and parts of a stand can, e.g., be damaged by strong winds or insects. The allocation of optimal treatment units may also be affected by external features, such as changes in wood prices.

The use of stands as description units have a long history. Already af Ström (1829) described how the forest, on the map, should be divided into areas, homogeneous with respect to variables such as age, volumes $\left(\mathrm{m}^{3} \mathrm{ha}^{-1}\right)$, etc. Stand data were described as mean values per description unit, and handled as such in the planning process. Until recent days, this way of treating spatial data were the only way to administrate the forest. 
With the introduction of computers, the stand concept might be outdated as suggested by Holmgren (1995). As the forest vary both spatially and temporally it might be effective to treat it as such. That is to introduce the concept of spatially and temporally dynamic description and treatment units.

One way to approach this is to describe the forest in grids, much smaller than the smallest thinkable treatment unit. For each grid of, e.g., $15 \times 15 \mathrm{~m}$ size, important forest management planning variables can be described and stored. Considering this complete spatial description of forest characteristics, it is possible to cluster the grid cells into the treatment units that best satisfies overall objectives, given assumptions about prices, costs and environmental considerations. However, this requires that such a close to continuous description of the forest is possible to accomplish without too high costs.

It is possible to estimate forest planning variables continuously over a forest holding by using different inventory techniques as described by, e.g., Newton \& Bower (1989), Ding \& Fotheringham (1992), Elston \& Buckland (1993) and Holmgren \& Thuresson (1996). Obviously, it would be too expensive to inventory all parts of a forest objectively. However, sample plots can be inventoried and by using a method called kriging a continuum can be created, for variables like volume per ha, site index or age.

The kriging method is an estimation procedure for regionalized variables. Regionalized variables is a concept in geostatistics, meaning a variable that has continuity from point to point, i.e. shows autocorrelation (Davis 1986, Ding \& Fotheringham 1992, Czaplewski et al. 1994). By the kriging method an estimate of the value of a variable is 
obtained at unrecorded places without bias and with a minimum variance. The variance is also possible to estimate. The method utilizes information about the spatial autocorrelation from semi-variograms.

One of the basic concepts in geostatistics is the semi-variance (Matheron 1963). It is a measure of the spatial dependence between values for two points at a certain distance (Burgess and Webster 1980, Samra et al. 1989, Höck et al. 1993). In a semi-variogram the semi-variance is plotted against distance. At distance zero the semi-variance is by definition zero. However, the semi-variance is in many cases discontinuous at zero, due to a pure random component (white noise). In addition measurement errors can strengthen this effect. The discontinuity is in geostatistical applications called the "nugget". For increasing distance the semi-variance is typically non-decreasing. It converges towards an asymptote, called the sill, which equals the population variance. The sill is usually reached for some finite distance, called the range of the regionalized variable. It defines the maximum distance within which point values have non-zero correlation coefficient.

The semi-variogram estimates at discrete distances (h) can be combined with regression technique to estimate the semi-variogram for all h. More often, distance classes are used for the estimator $\gamma_{h}$, and the value $\gamma_{h}$ obtained is considered as the semi-variogram value for the average distance of the plots within the class.

Kriging was first used in the mining industry to estimate the dispersion of valuable minerals. However, the method is applicable to any variable displaying spatial 
autocorrelation (Matheron 1963). The method has for instance been used in many investigations of soil properties (Burgess \& Webster 1980, Ponce-Hernandez \& Beckett 1989). Höck et al. (1993) used the method to estimate site index for Pinus radiata, Czaplewski et al (1994) estimated the growth of pine stands and Samra et al (1989) estimated height of Dharek (Melia azedarach). These investigations were carried out within stands and did not consider the possibility to increase spatial resolution by abandoning the stand concept.

Holmgren \& Thuresson (1996) used kriging to create spatially continuous estimations of four forestry planning variables to enable the formation of dynamic treatment units. Another way to achieve spatially continuous estimations of different planning variables is by using aerial photographs or satellite pictures. Holmgren \& Thuresson (1996) used both methods to create combined estimates. An objective circular plot inventory combined with remote sensing and geostatistics, thus formed the basis for the forest management planning. The continuous data were used to allocate treatment units according to present market conditions. One of the weaknesses in Holmgren \& Thuresson (1996) was that the estate was not representative for average Swedish forest conditions, since it was only partially cut and thus did not display any sharp stand boundaries.

In managed forests, there are sharp edges between old and young forests that cause discontinuities in forest management planning variables. If not considered this might cause kriging problems. The present study highlights if and how kriging can be applied 
on an intensively managed forests having those sharp edges between old and young forest.

It was also investigated if the standard error estimations from kriging is reliable in forest applications. 


\section{MATERIALS AND METHODS}

\section{Study area and reference data}

The study was carried out on a forest estate owned by the county board of forestry in Kronoberg. The 400 ha estate is located at Asa, in southern Sweden $\left(57^{\circ} 10^{`} \mathrm{~N}, 14^{\circ} 50^{`} \mathrm{E}\right)$. The forest is, for Swedish conditions, intensively managed, with a mean stand size of $2.8 \mathrm{ha}$. It is situated on sites with an average annual growth of $7.4 \mathrm{~m}^{3} \mathrm{sk} \mathrm{ha}^{-1}$ year ${ }^{-1}$ according to the objective circular plot inventory that was carried out in August 1995 within this study. According to the existing forest management plan, the average stocking was $144 \mathrm{~m}^{3} \mathrm{sk} \mathrm{ha}{ }^{-1}$ in 1994 . The objective inventory 1995 gave, by coincidence, the same value. In this the species composition by volume was: Pine (Pinus sylvestris) $44 \%$, Spruce (Picea abies) $52 \%$ and deciduous trees $4 \%$.

\section{Inventory method}

A problem when using kriging is, as mentioned in the introduction, sharp edges between, e.g., young and old forests. One way of reducing the problem with discrete jumps is to divide the forest into different strata. Then the field survey can also be emphasized on stands where high present net value (PNV) losses can be the result of wrong decisions. In this respect, information about old, well stocked stands are normally more important than information about younger ones. In this study the forest was 
divided into 4 different areal strata by age according to the (subjective) stand database. The four strata were: stands younger than 10 years; 10 - 30 years; 30 - 70 years; and stands older than 70 years. In each stratum clusters of three sample plots, each with a radius of $10 \mathrm{~m}$, were laid out in a systematic grid. The intensity of the inventory was highest in older parts. Within the clusters the plots were arranged in an "L"-shape with the lengths 30 and $40 \mathrm{~m}$ respectively on the two axis (N/S and E/W). Each cluster was randomly rotated in steps of $90^{\circ}$ and the two lengths $(30$ and $40 \mathrm{~m})$ were randomly given to the two axis (Fig. 1). In this way a distribution of pair-wise distances between plots was achieved, facilitating a study of spatial autocorrelation.

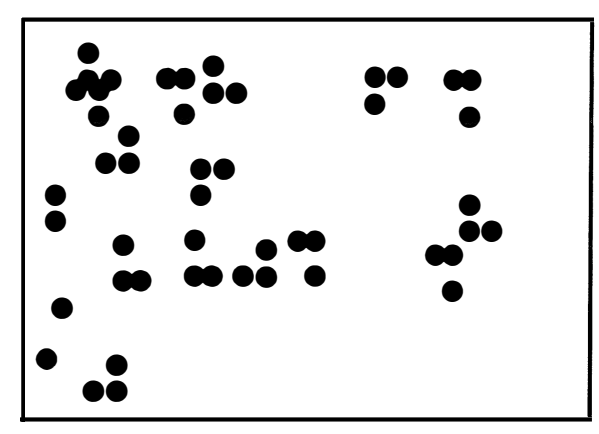

Figure 1. Map showing an example of the arrangement of sample plots in this study. Plots from more than one strata included in the Figure.

The positions of the plots were determined using Global positioning system (GPS) equipment with differential correction. A total of 40 positions over a period of 10 minutes were registered for each cluster. Each sample plot was inventoried using the Forest Management Planning Package (FMPP) (Jonsson et al. 1993) basic method. In short, all trees on the plots were calipered. Sample trees were sampled PPS to basal area, 
and variables such as height, living crown height, age, quality, etc., were measured. Site data such as site index, soil type and moisture class were also registered for each plot.

\section{Strategic plan}

The strategic plan were based on FMPP optimization without sustainability constraints using an interest rate of $3 \%$. Estimations of different forestry planning variables at each sample plot were made. Also the economic optimal treatments were estimated at plot level. Besides more or less measured variables such as volumes $\left(\mathrm{m}^{3} \mathrm{ha}^{-1}\right)$, ages, mean diameter, etc., calculated PNV figures such as inoptimality losses (IL) in Swedish crowns (SEK) ha ${ }^{-1}$ could, thus be estimated. These figures was further used in the autocorrelation studies.

\section{Spatial autocorrelation, semi-variance and semi-variograms}

The equation for computing the semi-variance based on sample data is:

$\gamma_{h}=\frac{1}{2 M(h)} \sum_{i=1}^{M(h)}\left\{z\left(x_{i}\right)-z\left(x_{i}+h\right)\right\}^{2}$

where $\gamma_{\mathrm{h}}$ is the estimated semi-variance at distance $\mathrm{h}, \mathrm{z}\left(\mathrm{x}_{\mathrm{i}}\right)$ is the value of a regionalized variable at location $x_{i}$ and $z\left(x_{i+h}\right)$ the value for the same variable at distance $h$ away. $M(h)$ is the number of pairs of observations at distance $h$. 
When constructing semi-variograms, semi-variance data at distance classes $(\mathrm{h})$ were fitted to a spherical model:

$$
\begin{array}{ll}
\gamma(h)=c_{0}+c\left\{\frac{3}{2} \frac{h}{a}-\frac{1}{2}\left(\frac{h}{a}\right)^{3}\right\} & \text { for } 0<\mathrm{h} \leq \mathrm{a} \\
\gamma(h)=c_{0}+c & \text { for } \mathrm{h}>\mathrm{a} .
\end{array}
$$

where $c_{0}$ is the sum of the nugget variance, $c_{0}+c$ is the population variance, $h$ is the distance and a is the range (Burgess \& Webster 1980).

\section{Kriging}

The information from the semi-variogram is used to make minimum variance linear estimates for all locations by a weighted sum of observations within the neighborhood of the location for the estimated value (Matheron 1963, Burgess \& Webster 1980, Samra et al 1989, Elston \& Buckland 1993, Höck et al 1993).

In this study semi-variograms for several inventoried forest variables were constructed to test to which extent these variables display spatial autocorrelation. This was considered important as few investigations have been carried out on this subject and it is crucial for the usefulness of the kriging method. 
To investigate if the autocorrelation was isothropic with respect to inclination, semivariograms were constructed with difference in height above sea level included.

Punctual ordinary kriging without trend were used to create estimations for a raster consisting of $18 \times 18 \mathrm{~m}$ squares. The size of the squares were chosen to be approximately the same as the size of the sample plots. A mask was created using the existing forest map, to exclude cells outside the estate or outside productive forest land.

To evaluate the result from the punctual kriging a jack-knife cross-validation approach was chosen. All sample plots were excluded one by one from the data set and estimated with kriging using the remaining sample plots. Measured and estimated values were then compared to evaluate the kriging results (Höck et al. 1993). The mean of the estimated standard deviations for the estimation at each plot was computed. This figure can be compared with the variance for the difference between estimated and measured values. The analysis were carried out separately for (a) strata 1 and 2 and (b) for strata 3 and 4 . 


\section{RESULTS}

\section{Semi-variograms}

Semi-variograms were constructed for a broad variety of forest management planning variables. For variables that displayed spatial autocorrelation, models of the semivariance were fitted. For all variables spherical models (Burgess and Webster 1980) were chosen. The results are summarized in Table 1. In Fig. 2 semi-variograms for six different variables are plotted, one of them (Hardwood volume) with no or little spatial autocorrelation.

Table 1. Subjectively fitted semi-variances based on sample plot data. (* Variable that show no or very little autocorrelation.)

\begin{tabular}{|c|c|c|c|c|}
\hline variable & $\sqrt{\text { nugget }}$ & range & $\sqrt{\text { variance }}$ & mean \\
\hline Total volume $\left(\mathrm{m}^{3} \mathrm{sk} \mathrm{ha}^{-1}\right)$, strata $1-4$ & 54.8 & 150 & 127 & 174 \\
\hline Total volume $\left(\mathrm{m}^{3} \mathrm{sk} \mathrm{ha}^{-1}\right)$, strata 1 and 2 & 0 & 180 & 69.7 & 51.5 \\
\hline Total volume $\left(\mathrm{m}^{3} \mathrm{sk}\right.$ ha $\left.{ }^{-1}\right)$, strata 3 and 4 & 83.7 & 250 & 110 & 224 \\
\hline Pine volume (Pinus sylvestris $)\left(\mathrm{m}^{3} \mathrm{sk} \mathrm{ha}^{-1}\right)$, strata $1-4$ & 41.2 & 125 & 87.8 & 67.1 \\
\hline Pine volume (Pinus sylvestris)(m3sk ha $\left.{ }^{-1}\right)$, strata 3 and 4 & 44.7 & 100 & 93.4 & 89.6 \\
\hline Spruce volume (Picea abies) $\left(\mathrm{m} 3 \mathrm{sk} \mathrm{ha}^{-1}\right)$, strata $1-4$ & 74.2 & 80 & 107 & 97.0 \\
\hline Hardwood volume $\left(\mathrm{m}^{3} \mathrm{sk} \mathrm{ha}^{-1}\right.$ year $\left.^{-1}\right)$ & $-*$ & & - & \\
\hline Total age (years), strata 1-4 & 0 & 200 & 35.2 & 52.6 \\
\hline Total age (years), strata 1 and 2 & 0 & 250 & 11.0 & 17.7 \\
\hline Total age (years), strata 3 and 4 & 13.4 & 150 & 31.5 & 66.8 \\
\hline IL Final felling (1000 SEK), strata 3 and 4 & 7.1 & 800 & 13.6 & 12,4 \\
\hline Total volume increment $\left(\mathrm{m}^{3} \mathrm{sk} \mathrm{ha}^{-1}\right.$ year $\left.^{-1}\right)$, strata $1-4$ & 1.6 & 250 & 4.46 & 7.36 \\
\hline Total volume increment $\left(\mathrm{m}^{3} \mathrm{sk}^{-1} \mathrm{year}^{-1}\right)$, strata 1 and 2 & 0 & 200 & 5.86 & 6.77 \\
\hline Total volume increment $\left(\mathrm{m}^{3}\right.$ sk ha $\mathrm{y}^{-1}$ year $\left.^{-1}\right)$, strata 3 and 4 & 1.9 & 700 & 3.72 & 7.60 \\
\hline SI Pine (Pinus sylvestris)(m), strata 1-4 & 0.55 & 200 & 1.06 & 27.4 \\
\hline SI Pine (Pinus sylvestris)(m), strata 3 and 4 & 0.67 & 200 & 1.17 & 27.3 \\
\hline SI Spruce (Picea abies)(m), strata 1-4 & 1.4 & 180 & 2.34 & 30.3 \\
\hline SI Spruce $($ Picea abies $)(\mathrm{m})$, strata 3 and 4 & 1.7 & 170 & 2.53 & 30.1 \\
\hline Dgv all species $(\mathrm{cm})$, strata $1-4$ & 0 & 200 & 11.0 & 20.3 \\
\hline Dgv all species $(\mathrm{cm})$, strata 1 and 2 & 0 & 300 & 6.4 & 9.20 \\
\hline
\end{tabular}




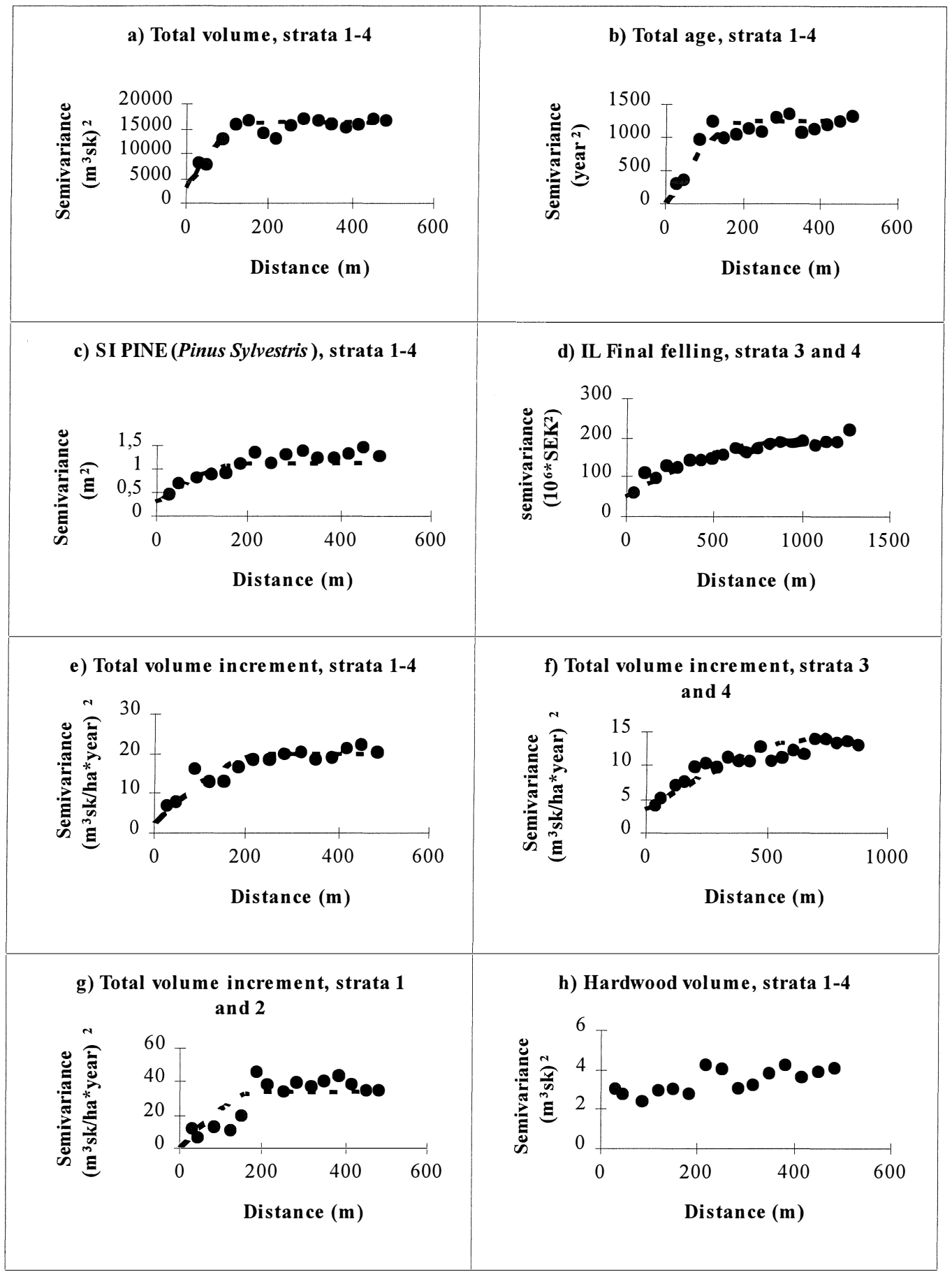

Figure 2. Semi-variograms based on sample plot data. Dotted lines represents the chosen model of the semi-variance for each variable. The hardwood volume is an example of a variable that shows no or little useful spatial autocorrelation. 


\section{Kriging results}

Punctual kriging for the forest estate, using the fitted semi-variogram models fitted (table 1) were applied for different planning variables useful for planning purposes. The result is displayed in the form of maps for total volume $\left(\mathrm{m}^{3} \mathrm{ha}^{-1}\right)$, site index $(\mathrm{m})$ for Picea abies and the inoptimal loss for final felling (SEK ha $\left.{ }^{-1}\right)($ Fig. 3 - 5).
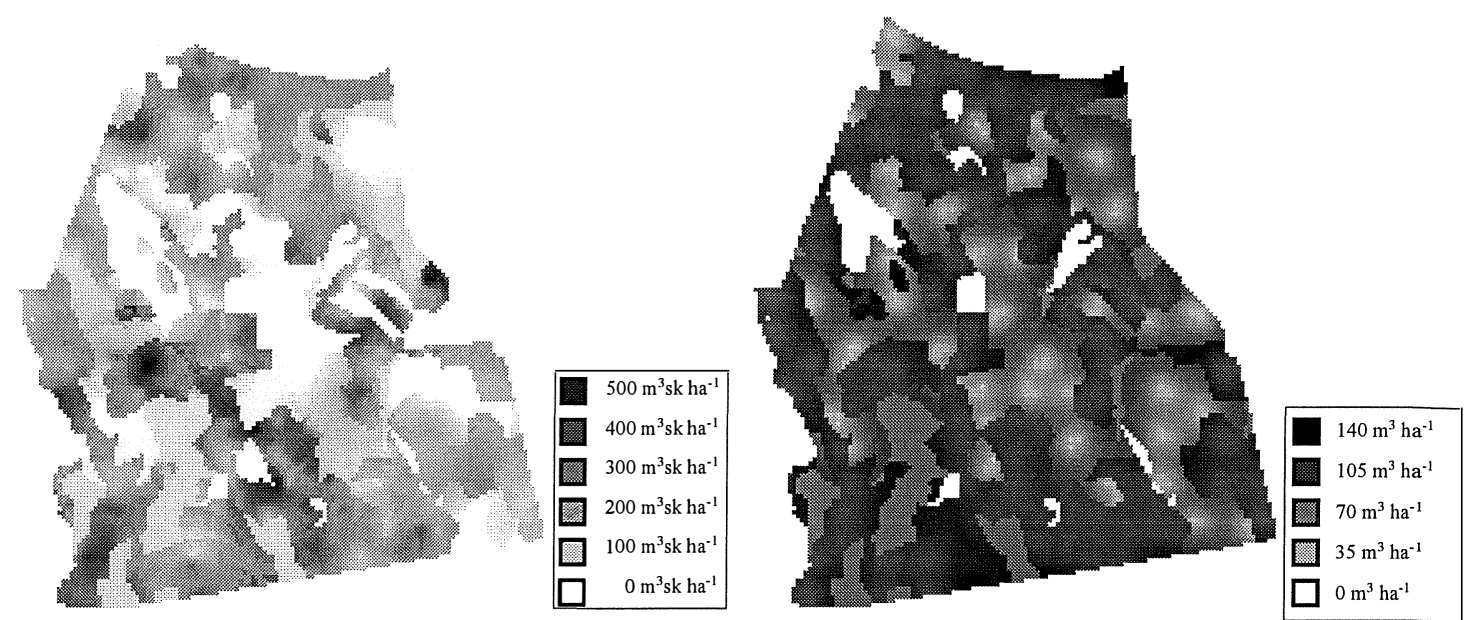

Figure 3. Maps showing the result from the kriging estimation of total volume $/ \mathrm{ha}\left(\mathrm{m}^{3} \mathrm{ha}^{-1}\right.$, left), and the standard errors of the estimates $\left(\mathrm{m}^{3} \mathrm{ha}^{-1}\right.$, right $)$. The estimation were done separately for (a) strata 1 and 2 and (b) for strata 3 and 4 . The volume ranges from 0 (white) to 590 (black) $\mathrm{m}^{3} \mathrm{ha}^{-1}$. 

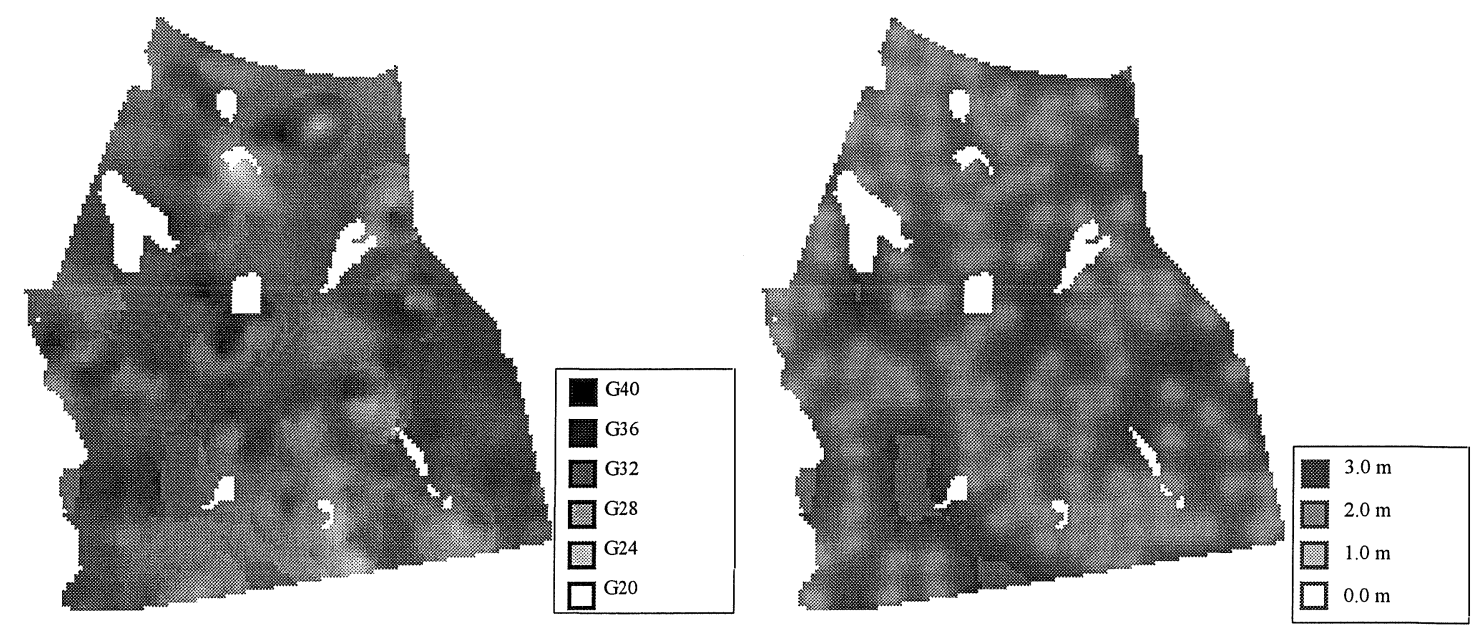

Figure 4. Maps showing the result from the kriging estimation of SI for spruce (Picea abies) (m, left) and the estimated value of the standard errors of the estimates ( $m$, right). The estimations were made for strata 1-4. The SI ranges from 18.0 (white) to 36.6 (black) m. Note the pattern of lower errors closer to the sample plots.
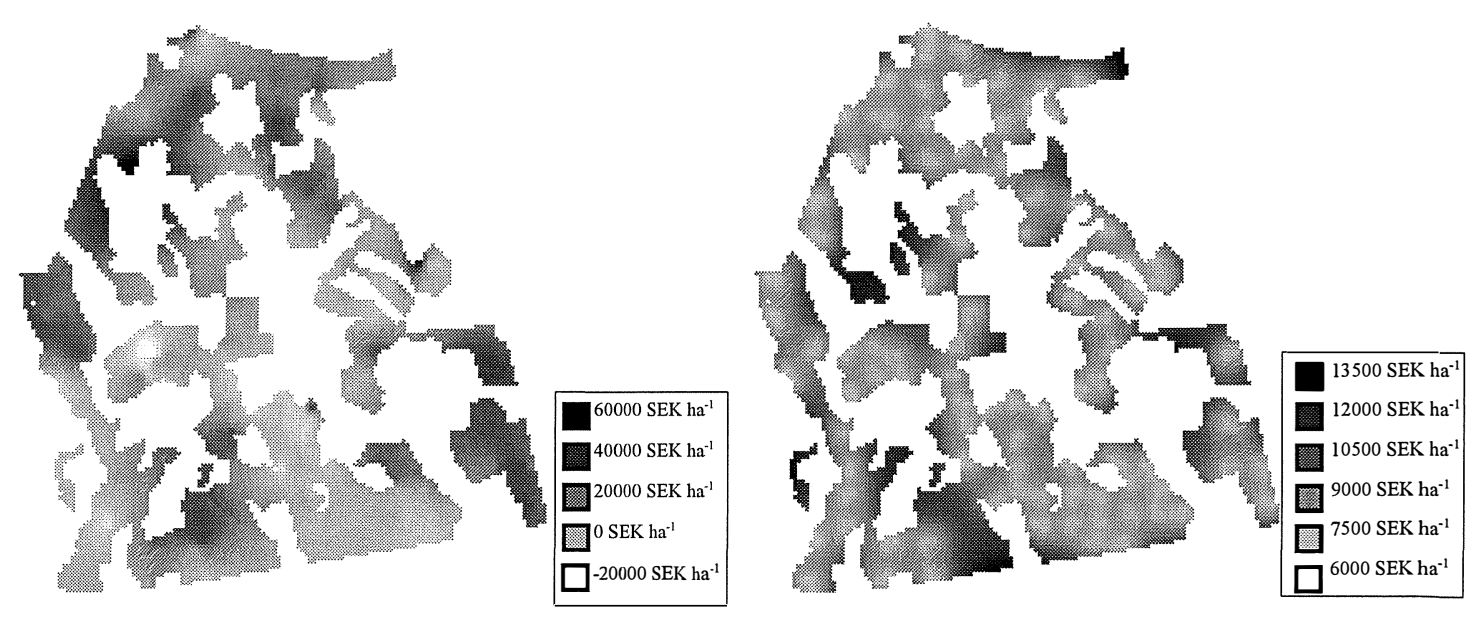

Figure 5. Map showing the result from the kriging estimation of IL final felling (SEK ha-1, left) and the corresponding figures for the standard errors of the estimates (SEK ha ${ }^{-1}$, right). The IL ranges from -22000 (white) to 60000 (black) SEK ha ${ }^{-1}$. The calculations were done for strata 3 and 4 only. 


\section{Evaluation of the kriging estimations}

The result from the jack-knife cross validation show, as expected, that the kriging estimations have a smaller variance than the measured data. Larger values is underestimated and lower is overestimated. The mean of the estimated standard deviation was $98.7 \mathrm{~m}^{3} \mathrm{ha}^{-1}$, the corresponding figure for the observed differences was $85.4 \mathrm{~m}^{3} \mathrm{ha}^{-1}$ 
Table 2. Comparison of the measured total volume $\left(\mathrm{m}^{3} \mathrm{ha}^{-1}\right)$ and the estimation of the same variable using kriging at the sample plots. The kriging estimation was carried out for each sample plot, with the estimated plot excluded from the material.

\begin{tabular}{|l|r|r|}
\hline & Measured total volume ha $\mathrm{ha}^{-1}\left(\mathrm{~m}^{3} \mathrm{ha}^{-1}\right)$ & Estimated total volume ha \\
\hline Mean & 173.8 & $\left.\mathrm{~m}^{3} \mathrm{ha}^{-1}\right)$ \\
\hline Variance & 16167 & 172.5 \\
\hline Minimum & 0 & 12512 \\
\hline Maximum & 607 & 0 \\
\hline
\end{tabular}

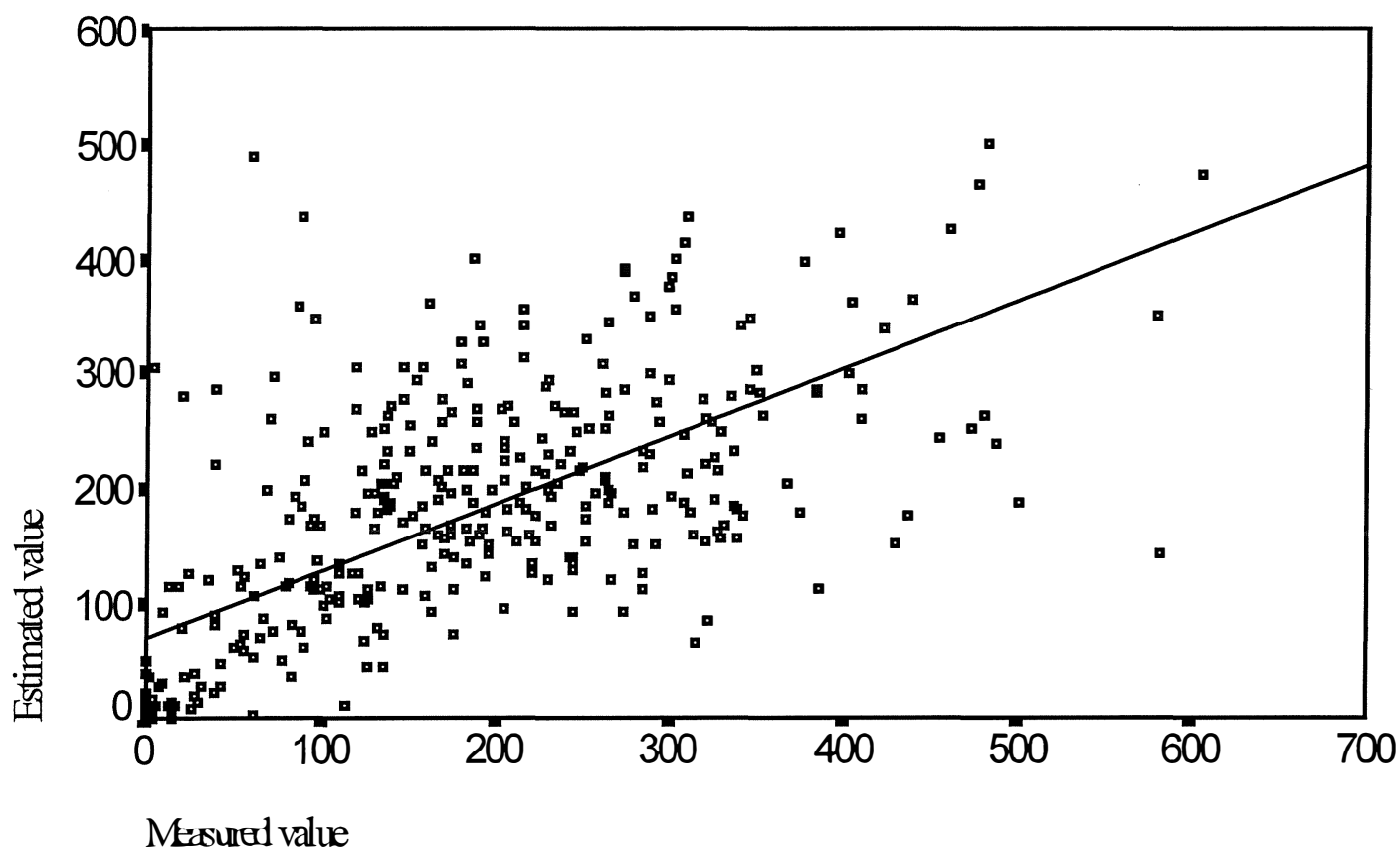

Figure 6. Comparison between estimated and measured total volume $\left(\mathrm{m}^{3} \mathrm{ha}^{-1}\right)$. The data from the jackknifing analysis of the material. Number of observations $=372$. The line in the figure shows the result from linear regression: estimated value $=70.6+0.59 *$ measured value. $\left(\mathrm{R}^{2}=0.44\right)$ 


\section{DISCUSSION}

Spatially continuous estimations of forest management planning variables, using kriging, may have several advantages compared to subjectively delineated fixed stands. The standard errors of the predictions are possible to estimate and the description of the forest is not restricted to predefined stands. Also, since the standard errors of the predictions can be estimated, the kriging prediction can be combined with other data sources, such as, e.g., aerial photographs (Holmgren et al. 1995). If the estimations are based on sample plots, the possibilities to forecast forest planning variables may be better than for subjectively surveyed stands. Planning algorithms that utilize spatially continuous data (e.g., Hof et al. 1996) can be developed for a more efficient forest management.

A lot of very sophisticated analyses are today based on old and not very accurate information. The result of such an analysis has no better precision than the information used - a fact often neglected. This article is investigating one method to possibly improve the information for forest management planning.

In this investigation circular sample plots were arranged in clusters of three at positions 30, 40 and $50 \mathrm{~m}$ apart, to be able to make good estimates of semi-variances at short distances and to study properties of the semi-variograms. For genuine planning purposes the optimal allocation of plots is probably another. The general precision properties are determined by the average distances from positions to the nearest sample plots. Thus, arranging the sample plots in clusters of two plots would bring about shorter distances 
between the clusters for the same cost and with better prediction possibilities. The two plots within a cluster could be arranged with varying distances and directions. This would give a denser grid of observations which should result in lower standard errors for a lot of pixels, still giving the necessary information to create the semi-variograms. If larger forest areas (more circular plots) are to be inventoried portions of the "clusters" could be single observations, still giving the same possibilities to estimate the semivariograms well at short distances.

The stratification of the forest seams necessary to handle the sharp gradients in a managed forest. In this study the strata were created using an existing forest map. Alternatively, recent aerial photographs can be used. It may be enough with two strata, one consisting of young forests with low volumes and one with older forest and high volumes.

The evaluation of the result from the kriging process shows, as expected, that the kriging estimates are smoothed compared to the measured values. Small values are often overestimated and large values underestimated. The nugget in the semi-variograms causes a big deal of this effect. The slight underestimation of the total volume per hectare (Table 2), estimated with kriging, is not a significant bias. The comparison between estimated standard errors of the kriging estimations and observed errors show that the error estimate is not misleading. The estimated mean standard error is a little higher than the observed. However, the arrangement of the plots in groups of three means that almost every plot in the jack-knife evaluation has two measured plots at short distances. The result indicates that the method works properly, but the result is valid 
only for shorter distances. On the other hand the mean error of the jack-knifing evaluation is higher than the true one, since the best information, i.e. the nearest observation, is removed from the material. The standard error is high, when calculated for one pixel, but when pixels are added together to form treatment units the mean standard error for the treatment unit will be much lower (Holmgren et al. 1995).

The results of this study looks promising. They indicate that kriging methods may be used on managed estates to create spatial continuous estimations for variables important to forest management planning. Variables such as total volume $\left(\mathrm{m}^{3} \mathrm{ha}^{-1}\right)$, age and total annual volume increment $\left(\mathrm{m}^{3} \mathrm{ha}^{-1}\right.$ year $\left.^{-1}\right)$, showed the necessary spatial autocorrelation for using kriging. However, some variables did not display any spatial autocorrelation, e.g., all the hardwood variables. The reason is probably that the proportion of deciduous trees is low (4\%) and also appear in a scattered distribution over the estate. Remote sensing may be a better method to estimate such non-continuous variables.

The estate is typical for many private estates in southern Sweden. The promising results of the study thus indicate that the kriging method could be generally successful also for intensively managed forests. Much research remain, however, before spatially continuous descriptions of forests can be applied in practice. 


\section{ACKNOWLEDGMENTS}

The author gratefully acknowledge the following individuals and organizations:

Assistant professor Sören Holm, Dr. Peter Holmgren and Dr. Tomas Thuresson. The county board of forestry in Kronoberg for providing the forest estate and funding parts of the investigation. The Brattås foundation and the Swedish Council of Forestry and Agricultural Research for funding other parts of the investigation. 


\section{REFERENCES}

Burgess, T.M., \& Webster, R. 1980. Optimal interpolation and isarithmetic mapping of soil properties. I: The semi-variogram and punctual kriging. Journal of Soil Science. 31: 315-331.

Baskent, E.Z., \& Jordan, G.A. 1991. Spatial wood supply simulation modeling. The Forestry Chronicle. Vol. 67(6): 610-621.

Czaplewski, R.L., Reich, R.M., \& Bechtold, W.A. 1994. Spatial Autocorrelation in Growth of Undisturbed Natural Pine Stands Across Georgia. Forest Science. 40(2): 314-328.

Davis, J. 1986. Statistics and Data Analysis in Geology. John Wiley \& Sons, New York. pp. 239-248, 383-404.

Ding, Y.\& Fotheringham, A.S. 1992. The integration of spatial analysis and GIS. Computers, environment and urban systems. 16: 3-19.

Elston, D.A. \& Buckland, S.T. 1993. Statistical modelling of regional GIS data: an overview. Ecological Modelling. 67: 81-102.

Hof, J., Bevers, M. \& Pickens J. 1996. Chance-Constrained Optimization with Spatially Autocorrelated Forest Yields. Forest Science 42(1): 118-123.

Holmgren, P. 1995. Geographic information for forestry planning. Department of Forest Soils. Swedish University of Agricultural Sciences. Report 68.70 pp. ISSN 0348-3398.

Holmgren, P. \& Thuresson, T. 1995, Avdelningsfritt skogsbruk - gränslöst flexibelt! Fakta Skog nr. 14. (In Swedish). ISSN 1400-7789. 
Holmgren, P. \& Thuresson, T. 1996. Applying Objectively Estimated and Spatially Continuous Forest Parameters in Tactical Planning to obtain Dynamic Treatment Units. Accepted for publication in Forest Science.

Holmgren, P., Thuresson, T. \& Holm, S. 1995. Estimating Forest Parameters in Scanned Aerial Photographs with respect to Requirements for Economical Management Planning. In: Holmgren, P. 1995. Geographic information for forestry planning. Dissertation. Department of Forest Soils. Swedish University of Agricultural Sciencies. Report 68. ISSN 0348-3398.

Höck, B.K., Payn, T.W. \& Shirley, J.W. 1993. Using a Geographic Information System and geostatistics to estimate site index of Pinus radiata for Kaingaroa Forest, New Zealand. New Zealand Journal of Forestry Science. 23(3): 264-277.

Jonsson, B., Jacobsson, J. \& Kallur, H. 1993. The Forest Management Planning Package - Theory and application. Studia Forestalia Suecica. 189. 56 pp.

Matheron, G. 1963. Principles of Geostatistics. Economic Geology. 58: 1246-1266.

Newton, C.M. \& Bower, S.T. 1989. Spatial Analysis of Forest Inventory Data. In: Stateof-the-art methodology of forest inventory. A symposium Proceedings, U.S. Forest Service, Pacific Northwest Research Station, General Technical Report. pp. 369-378. PNW-GTR-263.

Ponce-Hernandez, P. \& Beckett, P.H.T. 1989. Land qualities in space and time:

complementary use of soil maps and trend modelling for spatial interpolation of soil properties by kriging. Proceedings of a symposium organized by the International Society of Soil Science (ISSS), Wageningen, the Netherlands, 22-26 August 1988. J. Bouma \& A.K. Bregt (editors). Wageningen Pudoc 1989. ISBN 90-220-0973-4. 
Samra, J.S., Gill, H.S., \& Bhatia, V.K. 1989. Spatial Stochastic Modeling of Growth and Forest Resource Evaluation. Forest Science. 35(3): 663-676.

af Ström, I.A. 1829. Förslag till en förbättrad Skogshushållning i Sverige. Kungliga Lantbruksakademien, Stockholm, 299 pp. (In Swedish).

Thuresson, T. 1995. Tactical Forestry Planning - Common Sense Assisted by Computers, and Models linked to the Strategic Plan. Section of Forest Mensuration and Management. Swedish University of Agricultural Sciencies. Report 31. pp. 6-45. ISSN 0349-2133. 
Bilaga 1. Krigingresultat, totalvolym / ha

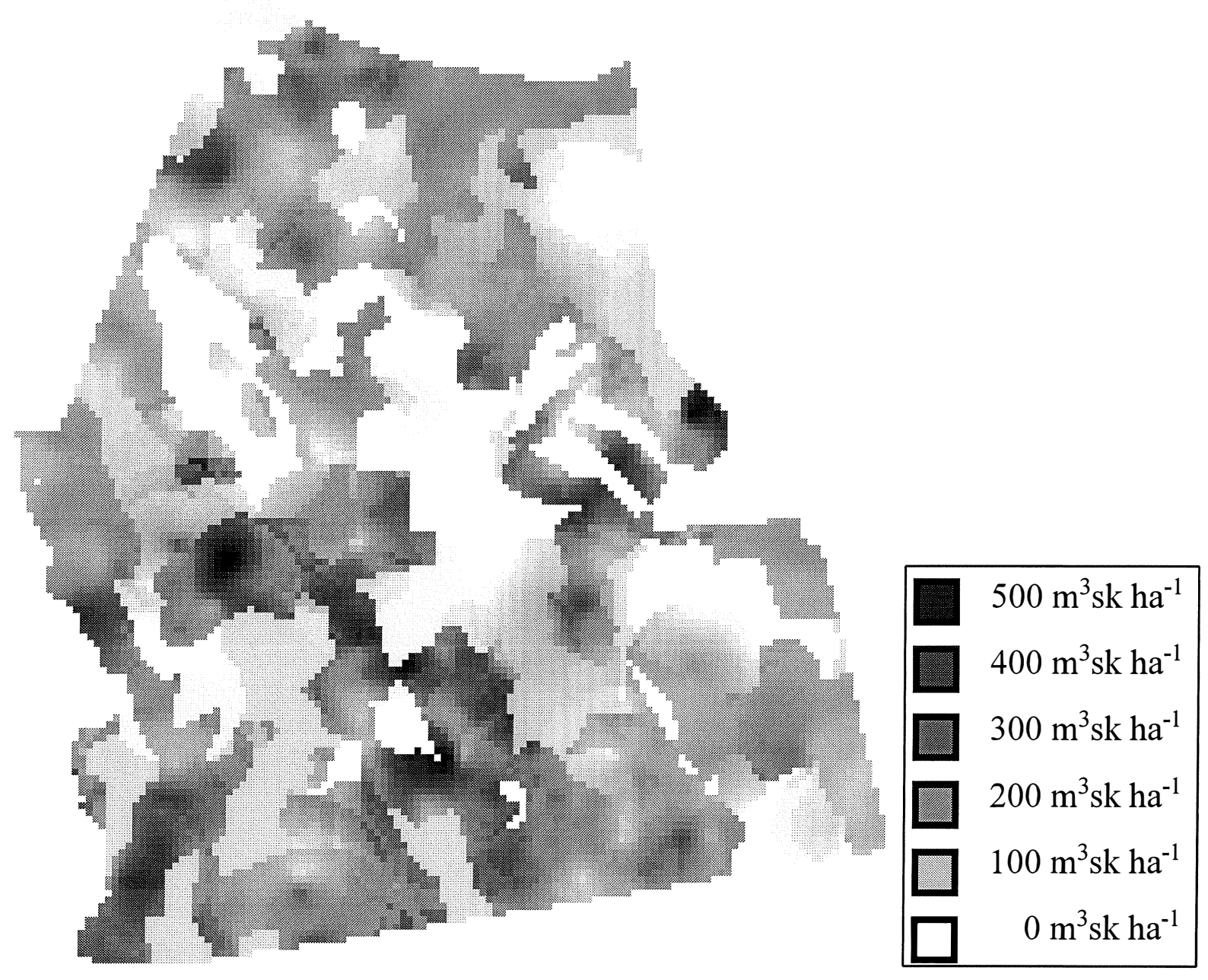


Bilaga 2. Krigingresultat, ståndortsindex för gran




Bilaga 3. Krigingresultat, inoptimalförlust vid slutavverkning

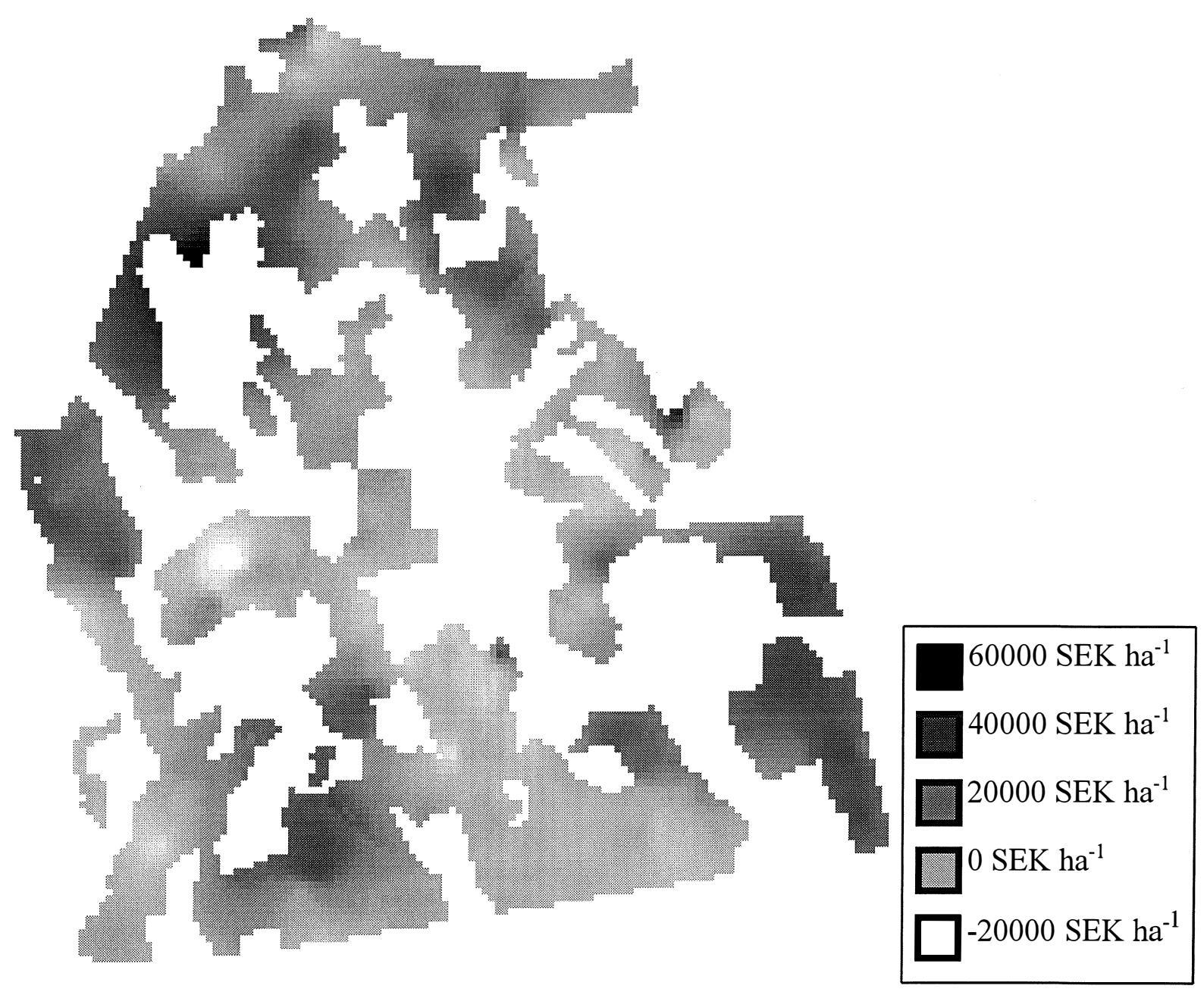


Bilaga 4. Krigingresultat, totalålder alla trädslag

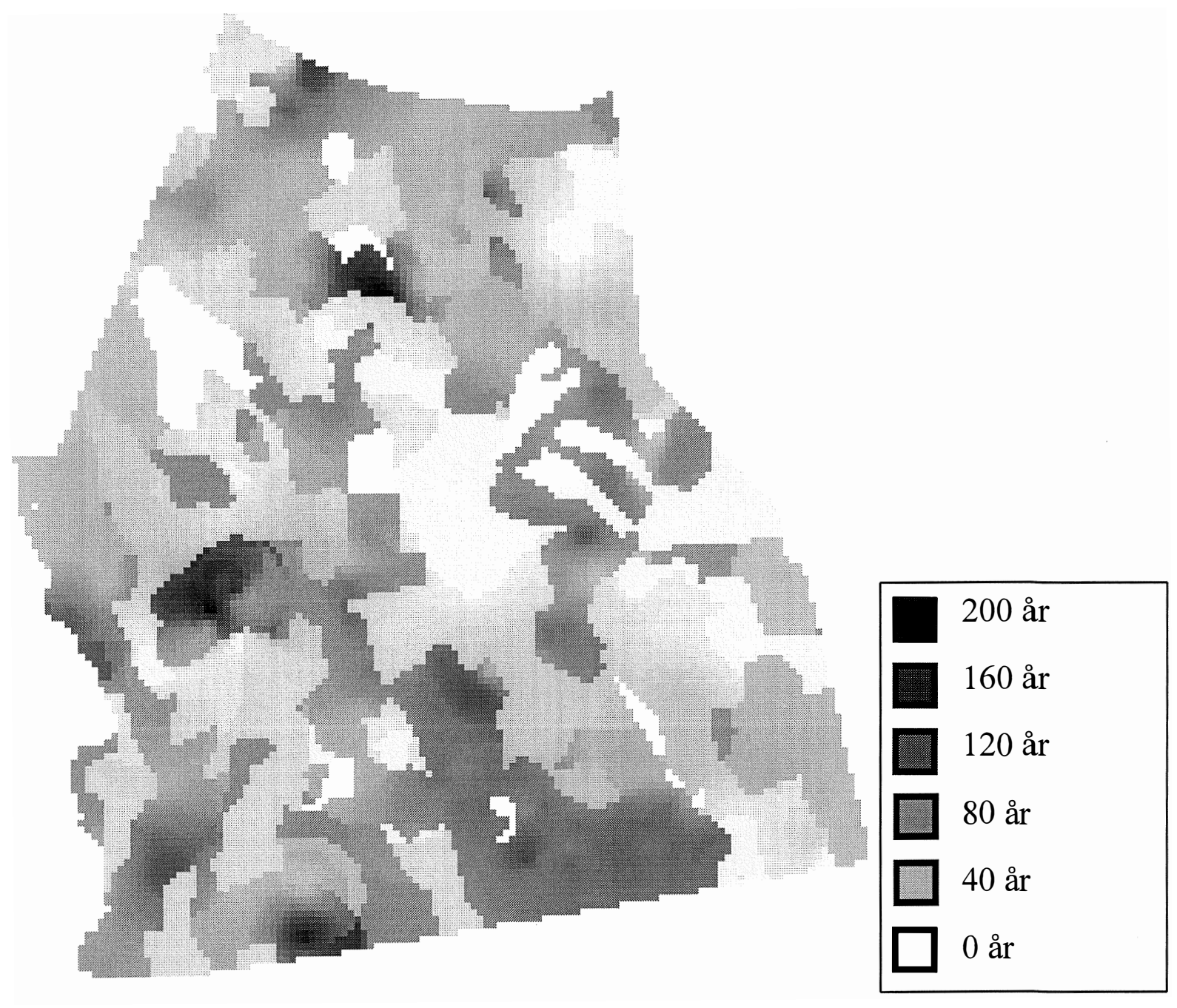


Serien Arbetsrapporter utges i första hand för institutionens eget behov av viss dokumentation.

Författarna svarar själva för rapporternas vetenskapliga innehåll.

19951 Kempe, G. Hjälpmedel för bestämning av slutenhet i plant- och ungskog. ISRN SLU-SRG-AR--1--SE

2 Riksskogstaxeringen och Ståndortskarteringen vid regional miljöövervakning. - metoder för att förbättra upplösningen vid inventering i skogliga avrinningsområden. ISRN SLU-SRG-AR--2--SE.

3 Holmgren, P. \& Thuresson, T. Skoglig planering på amerikanska västkusten - intryck från en studieresa till Oregon, Washington och British Columbia 1-14 augusti 1995. ISRN SLU-SRG-AR--3--SE.

4 Ståhl, G. The Transect Relascope - An Instrument for the Quantification of Coarse Woody Debris. ISRN SLU-SRG-AR--4--SE.

5 Törnquist, K. Ekologisk landskapsplanering i svenskt skogsbruk - hur började det?. Examensarbete i ämnet skogsuppskattning och skogsindelning. ISRN SLU-SRG-AR--5--SE.

19966 Persson, S. \& Segner, U. Aspekter kring datakvaliténs betydelse för den kortsiktiga planeringen. Examensarbete i ämnet skogsuppskattning och skogsindelning. ISRN SLU-SRG-AR--6--SE.

7 Henriksson, L. The thinning quotient - a relevant description of a thinning? Gallringskvot - en tillförlitlig beskrivning av en gallring? Examensarbete i ämnet skogsuppskattning och skogsindelning. ISRN SLU-SRG-AR--7--SE.

8 Ranvald, C. Sortimentsinriktad avverkning. Examensarbete i ämnet skogsuppskattning och skogsindelning. ISRN SLU-SRG--8--SE.

9 Olofsson, C. Mångbruk i ett landskapsperspektiv - En fallstudie på MoDo Skog AB, Örnsköldsviks förvaltning. Examensarbete i ämnet skogsuppskattning och skogsindelning. ISRN SLU-SRG--9--SE.

10 Andersson, H. Taper curve functions and quality estimation for Common Oak (Quercus Robur L.) in Sweden. Examensarbete i ämnet skogsuppskattning och skogsindelning. ISRN SLU-SRG--10--SE.

11 Djurberg, H. Den skogliga informationens roll i ett kundanpassat virkesflöde. - En bakgrundsstudie samt simulering av inventeringsmetoders inverkan på noggrannhet $\mathrm{i}$ leveransprognoser till sågverk. ISRN SLU-SRG--11--SE.

12 Bredberg, J. Skattning av ålder och andra beståndsvariabler - en fallstudie baserad på MoDo:s indelningsrutiner. ISRN SLU-SRG--12--SE. 
13 Gunnarsson, F. On the potential of Kriging for forest management planning. ISRN SLU-SRG--13--SE. 